\title{
Antimicrobial peptides: a new class of antimalarial drugs?
}

\author{
Nuno Vale, Luísa Aguiar and Paula Gomes* \\ Department of Chemistry and Biochemistry, Faculty of Sciences, Centro de Investigação em Química, University of Porto, Porto, Portugal
}

\section{Edited by:}

Miguel Castanho, University of

Lisbon, Portugal

\section{Reviewed by:}

Octavio Luiz Franco, Universidade Catolica de Brasilia, Brazil

Luis Rivas, Consejo Superior de

Investigaciones Científicas, Spain

\section{*Correspondence:}

Paula Gomes, Department of

Chemistry and Biochemistry, Faculty

of Sciences, Centro de Investigação

em Química, University of Porto, Rua

do Campo Alegre 687, 4169-007

Porto, Portugal

e-mail:pgomes@fc.up.pt
A range of antimicrobial peptides (AMP) exhibit activity on malaria parasites, Plasmodium spp., in their blood or mosquito stages, or both. These peptides include a diverse array of both natural and synthetic molecules varying greatly in size, charge, hydrophobicity, and secondary structure features. Along with an overview of relevant literature reports regarding AMP that display antiplasmodial activity, this review makes a few considerations about those molecules as a potential new class of antimalarial drugs.

Keywords: AMP, amphipathic, antimalarial, antimicrobial, cationic, membranolytic, peptide, Plasmodium spp.

\section{INTRODUCTION}

NATURAL ANTIMICROBIAL PEPTIDES: SOLDIERS IN THE BODY'S FIRST LINE OF DEFENSE

Once the organism is invaded by a pathogen, a primary response from the host immune system comprises production of specific peptides as defense compounds. Several of these humoral response peptides exert antibacterial, antifungal, or antiviral properties (Bulet et al., 1999) and are known as host defense peptides, or antimicrobial peptides (AMP; Bell, 2011). Hence, AMP form the first line of host defense against infection and are a key component of the ancient innate immune system. Most AMP are small amphipathic peptides, usually with $15-45$ amino acid (AA) residues, and, in general, are cationic at physiological $\mathrm{pH}$ (Boman, 2003).

Antimicrobial peptides, which may be encoded by separate genes or produced by non-ribosomal biosynthesis, have been identified in various species from bacteria to insects, amphibians to mammals, including humans (Zasloff, 2002; Pelegrini etal., 2011). In insects, AMP are synthesized in the fat body, in hemocytes, or epithelia, and are released into the hemolymph. In vertebrates, AMP are present in amphibian skin secretions (Simmaco et al., 1999) and epithelia (Ganz and Weiss, 1997; Bals etal., 1998); in mammals, AMP are also observed in lymphocytes (Agerberth et al., 2000) and leukocytes (Sorensen et al., 1997).

Because of their broad activity against microbes, and their expression triggered by various infections, AMP have been intensely examined as potential therapeutic agents (Zasloff, 2002). In 2004, the antimicrobial peptide database (APD, http://aps.unmc.edu/AP/main.php), created at the University of Nebraska Medical Center, already gathered a significant number of AMP that had been discovered at both the gene and protein levels (Wang and Wang, 2004). Later, APD has been updated and expanded to a second version that allows users to search peptides by families (e.g., bacteriocins, cyclotides, or defensins), sources (e.g., fish, frogs, or chicken), post-translational modifications (e.g., amidation, oxidation, lipidation, glycosylation, or inclusion of DAA), and binding targets [e.g., cell membranes, proteins, nucleic acids, lipopolysaccharides (LPSs), or other sugars; Wang et al., 2009]. Today, there is a huge plethora of AMP of both natural and synthetic origin, as recently reviewed elsewhere (Som et al., 2008; Rotem and Mor, 2009; Kuroda and Gaputo, 2013; Pushpanathan et al., 2013; Sgolastra et al., 2013), highlighting AMP as relevant antibiotics (Fjell et al., 2011).

\section{ORGANIZING DIVERSITY: STRUCTURE-BASED CLASSIFICATION OF ANTIMICROBIAL PEPTIDES}

The diversity of AMP reported since earlier disclosures in this area has soon made clear that some organization/classification of AMP families was needed. For instance, Boman (2003) proposed AMP to be split into three major groups: (a) linear $\alpha$-helical peptides free of cysteine residues; (b) $\beta$-pleated peptides containing disulfide bridges; (c) peptides with an overrepresentation of certain $\mathrm{AA}$, such as proline, arginine, tryptophan, or histidine. However, peptides that did not fit into any of these groups were later found to be antimicrobial, as is the case of circular peptides like $\theta$-defensins (Lehrer etal., 2012) or cyclotides (Jagadish and Camarero, 2010). Hence, at present, four main types of AMP can be roughly distinguished:

\section{$\alpha$-helical peptides deprived of Cys residues}

Linear cationic $\alpha$-helical AMP are a class of small peptides whose charge is imparted by the presence of multiple Lys and Arg, but also with a substantial portion (50\% or more) of hydrophobic residues. These peptides are known for their broad-spectrum antimicrobial activity and ability to modulate the innate immune response (Powers and Hancock, 2003). One example is that of melittin, an $\alpha$-helical cationic peptide from the venom of Apis mellifera bees, composed of 26 
AA residues and in which the amino-terminal region is predominantly hydrophobic whereas the carboxy-terminal region is hydrophilic due to the presence of a stretch of positively charged AA (Raghuraman and Chattopadhyay, 2007). Melittin is a potent antimicrobial that seems to promote membrane permeabilization through pore formation according to the toroidal model (Yang et al., 2001). However, its hemolytic activity is too high for clinical application as a selective AMP, which led to studies addressing synthesis and evaluation of the antimicrobial potential of hybrid peptide constructs where melittin (entire or partial AA sequence) was combined with other non-hemolytic AMP, such as cecropins (Boman et al., 1989; Bastos et al., 2008; López-Rojas etal., 2011). Cecropins constitute a well-known family of $\alpha$-helical AMP that share a similar structure containing two $\alpha$-helical domains linked by a flexible region. Insect cecropins are known to induce pore formation in negativelycharged bacterial membranes (Ekengren and Hultmark, 1999; Tanaka et al., 2008). In turn, a positive surface charge or cholesterol present in the membrane bilayer decreases the channel formation potency of cecropins (Christensen et al., 1988), which explains why these have little or no effect on eukaryotic cells (being non-hemolytic) that are richer in zwitterionic phospholipids and contain a high amount of cholesterol as compared to bacteria (Yeaman and Yount, 2003; Beevers and Dixon, 2010; Pretzel et al., 2013).

Other widely studied families of $\alpha$-helical, linear and cysteinefree AMP are those of magainins and dermaseptins, both naturally occurring in amphibians. Magainins 1 and 2 adopt an $\alpha$-helical conformation in solution (Zasloff, 1987), and have been proposed to induce toroidal pores in bacterial membranes (Ludtke et al., 1996). The non-hemolytic character of magainin 2 and its protocidal activity underlie its interest as a potential antiparasitic agent, and also as a template for creation of more potent large spectrum AMP analogs, such as pexiganan (Ge et al., 1999). In what concerns peptides from the dermaseptin super-family, these exhibit a broad range of antimicrobial activity and some of them were found to aggregate on the bacterial membrane surface in a carpet-like manner (Pouny etal., 1992).

\section{$\beta$-pleated peptides containing disulfide bridges}

A classical example of this group of AMP is that of defensins, peptides mostly found in mammalian phagocytes that usually contain six Cys residues (eight Cys have been found in some insect defensins) stabilizing peptide structure by forming three intramolecular disulfide bridges (Selsted et al., 1985). The mechanism of action of these peptides seems to also involve pore formation inducing membrane permeabilization, which is more extensive on negatively charged phospholipid bilayers (Lehrer et al., 1989; Wimley et al., 1994).

\section{Peptides rich in Pro, Gly, His, Arg, and Trp residues}

This is a somewhat more heterogeneous group of AMP, as those included are diverse in sequence and tridimensional structure, sharing the feature of having an overrepresentation of certain AA, specifically, Pro, Gly, His, Arg, and Trp. From this follows that AMP of this group seem to also have diverse mechanisms of antimicrobial action, in some cases apparently involving intracellular targets (Otvos, 2005).

A family of Pro-rich AMP is that of apidaecins, short peptides that may adopt a polyproline type II helical structure which could be the structural basis to bind to specific targets underlying its antibacterial activity (Li et al., 2006). In fact, apidaecins do not seem to interact with microbial membranes through formation of pores, but rather by an energy-driven, eventually transportermediated, process (Castle et al., 1999).

Gly-rich AMP have been found with variable sizes and without any clear sequence signature, apart from the high proportion (25-50\%) of glycine residues. These peptides are in general longer than AMP from other classes, have disordered structure in water, and tend to self-order when in contact with artificial membranes (Bruston et al., 2007). Attacins are family of six Glyrich AMP that can be divided into four basic (A-D) and two acidic (E-F) peptides, probably derived from two attacin genes (Yi et al., 2014). Attacins inhibit the synthesis of outer membrane proteins of Escherichia coli by blocking transcription of the respective genes (Carlsson et al., 1991), which is presumably achieved by an indirect mechanism, since attacins bind to the bacterial LPS but do not need to enter the cell to exert their action (Carlsson et al., 1998).

Tryptophan-rich AMP contain more than 25\% of this amino acid. In what concerns this class of AMP, the archetypical example is that of indolicin, which adopts no particular secondary structure in water, but seems to undergo significant structural changes in the vicinity of lipid bilayers, explaining its strong membrane affinity underlying its antimicrobial activity (Ladokhin and White, 2001). This peptide has the ability to permeate bacterial membranes and, depending of its tridimensional shape, inhibits DNA synthesis by binding to it (Hsu et al., 2005). Other examples of Trp-rich AMP include tritrpticin (Lawyer et al., 1996), lactoferricin B (Bellamy et al., 1992), and Pac-525 (Wei et al., 2006).

His-rich AMP usually have $25 \%$ of their AA content represented by His. In general, these peptides show a cationic amphipathic helical structure, and trigger microbial membrane disruption when adopting an alignment parallel to the membrane surface. Still, pore formation is not essential for the high antimicrobial activity of many His-rich AMP (Mason et al., 2009). Clavanin (van Kan et al., 2002), daptomycin (Jeu and Fung, 2004), LAH4 (Bechinger, 1996), or D-HALO-rev (Mason et al., 2009) are a few examples of this class of AMP.

\section{Circular antimicrobial peptides}

Discovery of antimicrobial activity on natural cyclic peptides that did not fit any of the previous three groups justifies the need to consider a fourth group, dedicated to circular AMP. $\theta$-defensins, for instance, fit this group: they are cyclic octadecamers active against several Gram-positive and Gram-negative bacteria, fungi, and some viruses, which consist of a couple of antiparallel $\beta$-sheets linked by three disulfide bonds to produce a very stable structure (Lehrer et al., 2012). Some bacteriocins, which are polypeptide toxins produced by bacteria to inhibit the growth of competing bacterial species or strain(s) (Cotter et al., 2013), are also circular AMP; that is the case of AS-48, a cyclic 70-mer bacteriocin from Enterococcus faecalis, possessing an overall globular structure 
where five $\alpha$-helices enclose a dense hydrophobic core (González et al., 2000). Finally, one of the most emblematic families of circular AMP is that of cyclotides (Jagadish and Camarero, 2010): these are plant-derived peptides, with approximately $30 \mathrm{AA}$, characterized by a head-to-tail cyclic backbone and three or four disulfide bonds forming the so-called cyclic cysteine knot (CCK; Craik et al., 1999), for which they are also known as "knotted peptides." As a result of their singular structure, these peptides are extremely stable, retaining their biological activity after boiling and being extremely resistant to enzymatic degradation (Vila-Perelló and Andreu, 2005; Craik and Conibear, 2011).

\section{ANTIMICROBIAL PEPTIDES: A NEW SOLUTION AGAINST MALARIA?}

\section{A MILLENARY WORLDWIDE DISEASE STILL FAR FROM ERADICATION}

Human malaria is caused by any of five species of protozoal, apicomplexan parasites of the genus Plasmodium, P. vivax, P. ovale, $P$. malariae, $P$. knowlesi, and P. falciparum, the latter being the most virulent, the best characterized, and (along with $P$. vivax) the most widespread species. Rodent malaria parasites such as $P$. berghei and $P$. yoelii, the avian parasite $P$. gallinaceum, or the human parasite $P$. falciparum are the most well-studied and used to evaluate drug-parasite interactions (Prudêncio et al., 2006; Dixon etal., 2008; Mantel etal., 2013; Regev-Rudzki etal., 2013). Parasites of the Apicomplexa are important animal pathogens notable for their complex life cycles and highly specialized invasive forms. Besides Plasmodia, apicomplexan parasites include the agents of toxoplasmosis, cryptosporidiosis, and several other significant parasitic diseases (WHO, 2012; Singh and Daneshvar, 2013).

The definitive host of Plasmodia, the female Anopheles mosquito, transmits the infective forms of the parasite, sporozoites, to the intermediate host (usually, a mammal) during its blood meal. After migration to the liver, the parasites develop within hepatocytes, of which they later exit as merozoites that are released into the bloodstream. Inside red blood cells (RBC) the asexual lifecycle takes place, starting by merozoite development into the ring stage, this in turn evolves to produce metabolically highly active trophozoites, which finally give place to schizonts, responsible for the release of new merozoites to infect other healthy RBC. Occasionally, ring forms can also develop into female and male gametocytes that, once ingested by another Anopheles mosquito, start the sexual lifecycle by developing into ookinetes, oocysts, and finally sporozoites, which migrate into the salivary gland to be transferred to another host on the following blood meal (Figure 1).

The complex life-cycle of malaria parasites, and the ease at which these undergo mutations to escape drug pressure, are the major factors behind both the limitations of current control methods and the urgent need for new chemoprophylactic and chemotherapeutic agents. These aspects have been comprehensively discussed elsewhere (Philips, 2001; Teixeira et al., 2014), turning clear that, while antimalarial drugs in use (mostly artemisinin and derivatives, quinolines or related compounds, and inhibitors of the folate pathway) can be effective in many situations, improvements in terms of (especially) cost and safety are highly desirable (Flannery etal., 2013; Visser et al., 2014; White et al., 2014). Yet, this is a difficult endeavor, as the mechanisms of action of many antimalarial drugs are still poorly understood. For instance, the current first-line antimalarial drugs, artemisinin and related compounds, have been suggested to eliminate the $\mathrm{Ca}^{2+}$-dependent ATPase activity of PfATP6 (Eckstein-Ludwig et al., 2003); however, other modes of action have been attributed to this family of antimalarials as, e.g., binding to ferriprotoporphyrin IX (a by-product of hemoglobin degradation), free radical-mediated damage or interference with hematin polymerization and detoxification (Robert et al., 2002; Biagini et al., 2003). Other antimalarial drugs seem to target the redox systems of Plasmodia, whose survival is highly dependent on the antioxidative stress system of their hosts (Becker etal., 2004). An example is that of chloroquine, formerly used as first-line treatment for uncomplicated malaria, which inhibits polymerization of toxic heme $\left(\mathrm{Fe}^{2+}\right)$ into hemozoin inside the parasite's food vacuole (Sullivan etal., 1996). Primaquine, which remains the only transmission-blocking antimalarial clinically available worldwide, seems to equally target the parasite's redox system; this drug displays marked activity against gametocytes of all species of human malaria, including multi-resistant $P$. falciparum strains, and is also effective against all exoerythrocytic forms of the parasite, including hypnozoites, dormant liver forms responsible for relapse of vivax and ovale malaria. Unfortunately, as many other clinically relevant antimalarials, primaquine is often associated with serious adverse effects, in consequence of its toxic metabolites (Vale et al., 2009).

Another drawback in antimalarial containment has emerged from misuse of available drugs, and marketing of fake ones, leading to widespread resistance. This has been the major factor behind chloroquine's loss of prominence in the antimalarial arsenal from the 1980s onward, and is also becoming a cause of concern regarding 21st century first-line artemisininbased combination therapies (ACT): the first signs of plasmodial resistance to artemisinin emerged in Southeast Asia in 2008 (Dondorp et al., 2009).

The above explains why malaria eradication is still out of reach and why the need to feed the antimalarial drug pipeline remains an urgent problem. In this connection, membrane-active peptides (MAP), such as most AMP, may offer interesting solutions, as by having cell membranes as their primary targets, their action will be harder to fight back by malaria parasites.

\section{ANTIMICROBIAL PEPTIDES WITH ANTIMALARIAL PROPERTIES}

There have been numerous reports on peptides active against various cultured stages of malaria parasites and/or in animal models of malaria. The range of size, AA composition, and secondary structure of such peptides is impressive, going from dipeptides up to polypeptides large enough to be considered as proteins. Antimalarial activity has been described for several substrate analogs of different plasmodial peptidases involved in host hemoglobin degradation, host-cell invasion and egress, and intracellular housekeeping (Blackman, 2004; Wegscheid-Gerlach et al., 2010). One interesting example is that of the ankyrin peptide (AnkP), a potent inhibitor of the major cysteine protease of $P$. falciparum, falcipain-2, which was delivered into parasite-infected red blood 


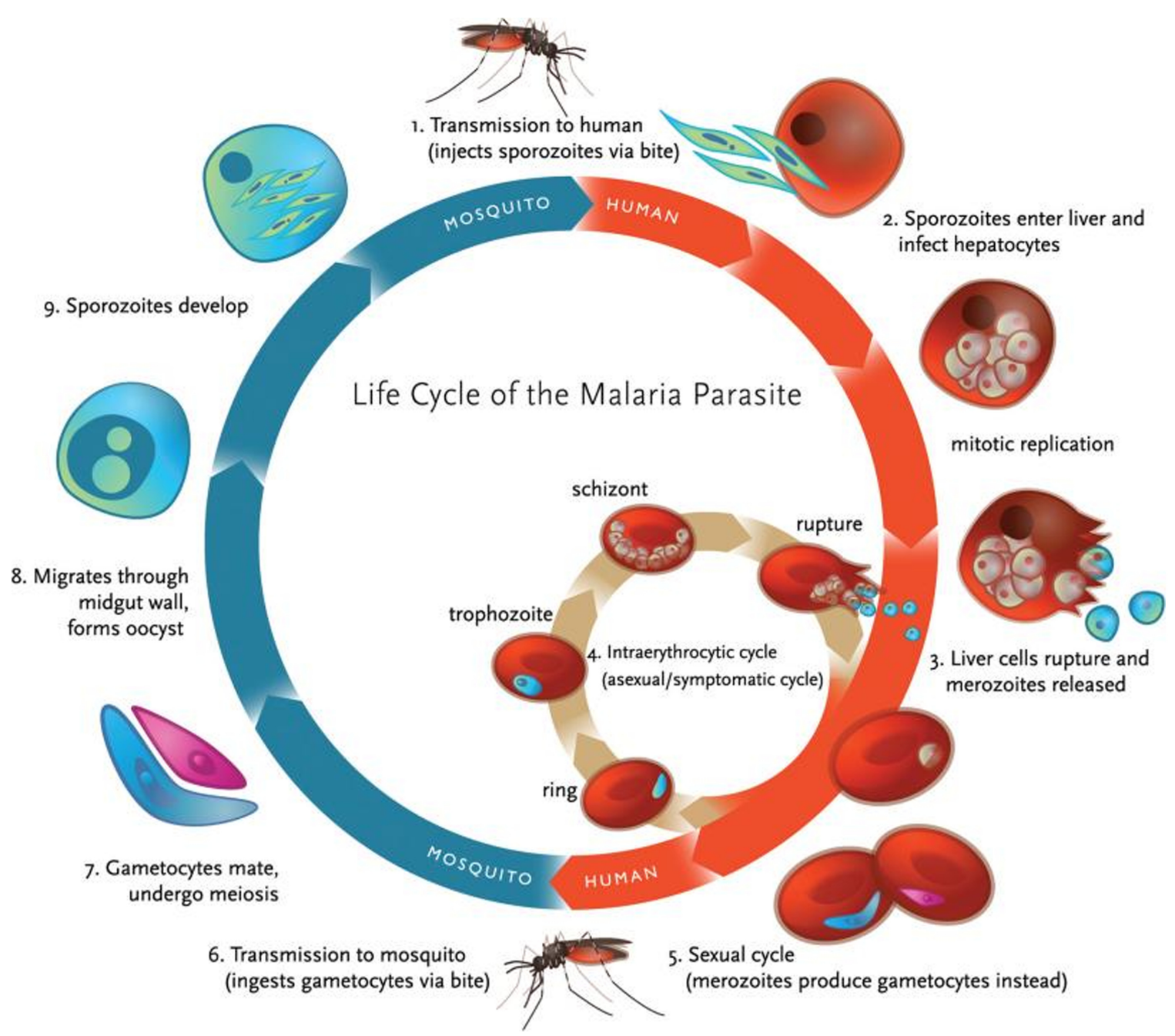

FIGURE 1 | Life cycle of malaria parasite. Malaria transmission occurs through a vector, the female Anopheles mosquito, which ingests gametocytes (the only infective form to mosquitoes) when feeding on infected blood (adapted with permission from Klein, 2013).

cells (PfRBC) via the Antennapedia homeoprotein internalization domain; this served to demonstrate not only the antimalarial properties of peptidase substrate analogs like AnkP, but also the potentially useful role of another class of MAP, the cell-penetrating peptides/proteins (CPP), for intracellular delivery of antimalarials (Dhawan etal., 2003). There have been also many reports on synthetic peptides or protein fragments with specific targets at parasite/host or parasite/vector interfaces, for instance, peptide fragments of adhesins that are involved in host-cell invasion (Malpede and Tolia, 2014).

Many broad-spectrum AMP from various sources, including anopheline mosquitoes (malaria vectors), have also been found to exhibit different degrees of antimalarial action (Bell, 2011). The fact that Plasmodia are eukaryotes may appear incompatible with the general notion that selective AMP preferentially target negatively-charged prokaryote membranes; however, the phospholipid composition of membranes from intraerythrocytic parasites are markedly different from those of their host eukaryote cells, RBC; moreover, upon infection by $P$. falciparum, $\mathrm{RBC}$ undergo significant changes in their membranes, whose composition gets closer to that of parasitic membranes (Hsiao et al., 1991). For instance, as compared to healthy RBC, PfRBC have increased contents of phosphatidylinositol and phosphatidic acid, and decreased contents of sphingomyelin, whereas phosphatidylethanolamines remain more or less unchanged (Hsiao et al., 1991). In other words, PfRBC membranes differ from those of healthy RBC; this, together with the fact that mechanisms of antimalarial action by AMP remain unknown, explains why the paradox of AMP exhibiting antiprotozoal action is only apparent. This comes in agreement with findings from Gelhaus et al. (2008), who found that NK-2, a small cationic AMP, while hardly affecting healthy RBC, promptly internalized PfRBC, affecting the viability of intracellular parasites; studies with liposomes, by the same authors, revealed a phosphatidylserine-dependent lysis by NK-2, which indicates that small cationic AMP may be selective to PfRBC, hence, emerging as a potential new class of antimalarials. In fact, a 
range of natural and synthetic AMP were found to have promising anti-plasmodial properties (Table 1), showing that modulation of the innate immune response is an effective approach to novel peptide anti-infective agents (Haney and Hancock, 2013). Another relevant example is that of phylloseptin-1(PS-1), an AMP capable to control the growth and cause in vitro destruction of $P$. falciparum, at the concentration of $16 \mu \mathrm{g} / \mathrm{mL}$, well-below the levels at which this peptide is toxic to mammalian cells (Kückelhaus et al., 2009). More examples of antimalarial AMP are next revised in higher detail.

\section{Cecropins and derivatives}

Cecropins, from the moth Hyalophora cecropia, disturb the development of oocysts into sporozoites, with a 50\% lethal dose between 0.5 and $1 \mu \mathrm{g} / \mu \mathrm{L}$ (Gwadz et al., 1989). Synthetic derivatives of cecropins have also been produced and analyzed for their effects against malaria: SB-37, highly similar to cecropin B, and Shiva-1, with $40 \%$ homology to the same cecropin from $H$. cecropia, were significantly lytic to $P$. falciparum blood stage forms at $50 \mu \mathrm{M}$; still, while SB-37 was equipotent to cecropin $\mathrm{B}$, Shiva-1 was twice as active as this cecropin (Jaynes et al.,

Table 1 | Antimicrobial peptides reported as active against Plasmodium spp. parasites.

\begin{tabular}{|c|c|c|}
\hline Peptide & Sequence/origin/reference & Activity \\
\hline $\mathrm{CA}(1-13) \mathrm{M}(1-13)$ & $\begin{array}{l}\text { KWKLFKKIEKVGQGIGAVLKVLTTGL Cecropin A/melittin hybrid (Frederik } \\
\text { et al., 1989) }\end{array}$ & $\mathrm{IC}_{50} 10 \mathrm{mM}(\mathrm{PfRBC})$ \\
\hline Cecropin B & $\begin{array}{l}\text { KWKVFKKIEKMGRNIRNGIVKAGPAIAVLGEAKALG Hyalophora cecropia } \\
\text { (Gwadz etal., 1989) }\end{array}$ & $\begin{array}{l}\text { 81-94\% abortion of oocyst development } \\
\text { (Plasmodium spp.) at } 0.5 \mu \mathrm{g} / \mu \mathrm{L}(128 \mu \mathrm{M})\end{array}$ \\
\hline Defensin A & $\begin{array}{l}\text { ATCDLLSGFGVGDSACAAHCIARGNRGGYCNSKKVCVCRN Aedes aegypti } \\
\text { (Kokoza et al., 2010) }\end{array}$ & $\begin{array}{l}\sim 85 \% \text { inhibition of oocyst proliferation in } \\
\text { transgenic mosquitoes (P. gallinaceum) }\end{array}$ \\
\hline Dermaseptin $\mathrm{DS}_{3}$ & $\begin{array}{l}\text { X-ALWKNMLKGIGKLAGKAALGAVKKLVGAES Phyllomedusa sauvagii } \\
\text { (dermaseptin derivative) (Ghosh et al., 1997) }\end{array}$ & $\mathrm{IC}_{50} 0.8-1.5 \mu \mathrm{M}(\mathrm{PfRBC})$ \\
\hline Dermaseptin $\mathrm{DS}_{4}$ & $\begin{array}{l}\text { X-ALWMTLLKKVLKAAAKAALNAVLVGANA Phyllomedusa sauvagii } \\
\text { (dermaseptin derivative) (Ghosh etal., 1997) }\end{array}$ & $\mathrm{IC}_{50} 0.27-2.2 \mu \mathrm{M}(\mathrm{PfRBC})$ \\
\hline D -HALO-rev & AKKLOHALHOALLALOHLAHOLLAKK Synthetic (Mason et al., 2009) & $\mathrm{IC}_{50} 0.1 \mu \mathrm{M}(\mathrm{PfRBC})$ \\
\hline Drosomycin & $\begin{array}{l}\text { DCLSGRYKGPCAVWDNETCRRVCKEEGRSSGHCSPSLKC-WCEGC } \\
\text { Drosophila melanogaster (Tian et al., 2008) }\end{array}$ & $\begin{array}{l}70 \% \text { gametocytes inhibition at } 20 \mu \mathrm{M}(P \text {. } \\
\text { berghei) }\end{array}$ \\
\hline Gambicin & $\begin{array}{l}\text { MVFAYAPTXARXKSIGARYXGYGYLNRKGVSXDGQTTIN- } \\
\text { SXEDXKRKFGRXSDGFIT Anopheles gambiae (Vizioli et al., } \\
\text { 2001) }\end{array}$ & $54.6 \%$ ookinetes killed at $10 \mu \mathrm{M}$ (P. berghei) \\
\hline IDR-1018 & $\begin{array}{l}\text { VRLIVAVRIWRR Bactenicin derivative (bovine neutrophils) (Wieczorek } \\
\text { etal., 2010) }\end{array}$ & Protection against cerebral malaria \\
\hline Dermaseptin K4K20-S4 & $\begin{array}{l}\text { ALWKTLLKKVLKAAAKAALKAVLVGANA Phyllomedusa sauvagii } \\
\text { (dermasepin S4 derivative) (Krugliak et al., 2000) }\end{array}$ & $\mathrm{IC}_{50} 0.2 \mu \mathrm{M}(\mathrm{PfRBC})$ \\
\hline Dermaseptin K4-S4(1-13)a & $\begin{array}{l}\text { ALWMTLLKKVLKA Phyllomedusa sauvagii (Dermasepin S4 derivative) } \\
\text { (Krugliak etal., 2000) }\end{array}$ & $\mathrm{IC}_{50} 6 \mathrm{mM}(\mathrm{PfRBC})$ \\
\hline Dermaseptin NC7-P & $\begin{array}{l}\mathrm{H}_{2} \mathrm{~N}-\left(\mathrm{CH}_{2}\right)_{6}-\mathrm{CO}-\mathrm{ALWKTLLKKVLKA-NH}{ }_{2} \text { Phyllomedusa sauvagii } \\
\text { (dermaseptin K4-S4(1-13)a derivative) (Efron et al., 2002) }\end{array}$ & $\begin{array}{l}\mathrm{IC}_{50} 5.3 \mu \mathrm{M}(\mathrm{PfRBC}, \text { ring stage); } 6.2 \mu \mathrm{M} \\
\text { (PfRBC, trophozoites) }\end{array}$ \\
\hline Magainin 2 & GIGKFLHSAKKFGKAFVGEIMNS Xenopus laevis (Frederik et al., 1989) & $\begin{array}{l}\text { 82-95\% abortion ofoocyst development } \\
\text { (Plasmodium spp.) at } 0.5 \mu \mathrm{g} / \mathrm{mL}(203 \mu \mathrm{M})\end{array}$ \\
\hline NK-2 & KILRGVCKKIMRTFLRRISKDILTGKK Synthetic (Gelhaus et al., 2008) & $\mathrm{IC}_{50} 1-10 \mu \mathrm{M}(\mathrm{PfRBC})$ \\
\hline SB-37 & $\begin{array}{l}\text { MPKWKVFKKIEKVGRNIRNGIVKAGPAIAVLGEAKALG Synthetic cecropin B } \\
\text { derivative (Jaynes et al., 1988) }\end{array}$ & $\mathrm{IC}_{50} \sim 50 \mu \mathrm{M}(\mathrm{PfRBC})$ \\
\hline Scorpine & $\begin{array}{l}\text { GWINEEKIQKKIDERMGNTVLGGMAKAIVHKMAKNEFQ- } \\
\text { CMANMDMLGNCEKHCOTSGEKGYCHGTKCKCGTPLSY Pandinus } \\
\text { imperator (Conde et al., 2000; Carballar-Lejarazu et al., 2008) }\end{array}$ & $\begin{array}{l}\mathrm{IC}_{50}: 1 \mu \mathrm{M} \text { (P. berghei ookinetes); } \sim 10 \mu \mathrm{M}(P . \\
\text { berghei gametes) }\end{array}$ \\
\hline Shiva-1 & $\begin{array}{l}\text { MPRWRLFRRIDRVGKQIKQGILRAGPAIALVGDARAVG Synthetic cecropin } \\
\text { B derivative (Jaynes et al., 1988) }\end{array}$ & $\mathrm{IC}_{50} \sim 20 \mu \mathrm{M}(\mathrm{PfRBC})$ \\
\hline Vida1 Vida 2 Vida 3 & $\begin{array}{l}\text { KWKKFKKGIGKLFV KWPKFKKGIPWLFV KWPKFRRGIPFLFV Synthetic } \\
\text { cecropin B/melittin hybrids (Arrighi et al., 2002) }\end{array}$ & $\begin{array}{l}\geq 60 \% \text { mortality of young } P \text {. berghei ookinetes } \\
\text { at } 50 \mu \mathrm{M}\end{array}$ \\
\hline
\end{tabular}


1988). The effect of another cecropin-like peptide, Shiva-3, on in vitro ookinete development and on the early sporogonic stages of $P$. berghei in the midgut of Anopheles albimanus mosquitoes was investigated; peptide concentrations of 75 and $100 \mu \mathrm{M}$ were effective in reducing ookinete production and the number of infected mosquitoes in almost all experiments (Rodriguez et al., 1995).

Hybrids of non-hemolytic cecropins with the potent bee venom toxin melittin have been found to inhibit RBC re-invasion by P. falciparum; an example of one such hybrid is that of CA(113) $\mathrm{M}(1-13)$, which is an order of magnitude more potent than magainin, cecropin $\mathrm{A}$, and cecropin $\mathrm{B}$, and is active in the 5-10 $\mu \mathrm{M}$ range (Frederik et al., 1989). More recent cecropinmelittin hybrids Vida1 (mainly consisting of $\alpha$-helices), Vida2 (essentially composed by $\beta$-sheets), and Vida3 (a combination of coils and sheets) were developed and tested against $P$. berghei and $P$. yoelii gametocytes. The mortality rate of: Vidal was $65 \%$ on young ookinetes $(10 \mathrm{~h})$, Vida2 was $60-70 \%$ on maturing ookinetes (14 and $24 \mathrm{~h}$ ), and Vida3 was higher than $60 \%$ throughout the entire developmental period (Arrighi et al., 2002). The antimalarial activity of Vida3 was associated to blockage of Plasmodium oocyst development, and the peptide was further found as toxic to Anopheles gambiae cells at $25 \mu \mathrm{M}$ (Carter et al., 2013).

The exact molecular mechanisms of membrane activity of cecropins have been under debate for more than 30 years, with two general models being proposed: formation of transmembrane pores, and the carpet model (Melo etal., 2009). A recent study demonstrates that cecropins A and $\mathrm{B}$ produce well-defined ion channels of different conductance levels in bilayer lipid membranes; further increase in peptide concentration causes destabilization and subsequent breakdown of the bilayer, showing that formation of pores is a first stage of membrane destabilization by these two cecropins, while accumulation of a dense peptide carpet precedes complete bilayer disintegration (Efimova etal., 2014).

\section{Amphibian antimalarial peptides: dermaseptins, magainins}

Dermaseptins, from the skin of Phyllomedusa frogs, are highly active against intraerythrocytic forms of different $P$. falciparum strains, with $\mathrm{IC}_{50}$ values between 0.8 and $2.2 \mu \mathrm{M}$ (Matsuda and Koyasu, 2000). A truncated dermaseptin derivative was found to exert anti- $P$. falciparum activity within less than $1 \mathrm{~min}$ after exposure, involving permeabilization of the host cell membrane (Bell et al., 2006). In order to decrease hemolytic activity of dermaseptins, aminoheptanoyl derivatives were synthesized; a screening against $P$. falciparum revealed higher activity for the more hydrophobic dermaseptin derivatives, some of which showing significant selectivity between antiplasmodial activity versus hemolytic activity (Efron et al., 2002; Gavigan et al., 2003).

Following discovery of antiplasmodial activity of the 28residue AMP dermaseptin S4 (Ghosh et al., 1997), a derived 13-residue AMP, K4-S4(1-13), was found to display considerable in vitro efficacy on P. falciparum (Krugliak et al., 2000). The antiplasmodial action of K4-S4(1-13) was fast and shown to be mediated by permeabilization of host cell plasma membrane. Although K4-S4(1-13) was less hemolytic to healthy RBC than to PfRBC, selectivity was not high enough and turned evident the necessity to develop additional derivatives active on parasites but with minimal threat to normal erythrocytes. Recently, acyl derivatives of K4-S4(1-13) were shown to have increased antiplasmodial activity, but the most potent of them was still significantly hemolytic (Dagan et al., 2002).

\section{Antimalarial peptides from insect vectors of parasitic diseases}

Antimicrobial peptides of insect origin have been found which display antimalarial properties. Drosomycins, isolated from Drosophila melanogaster, are an example of insect antimalarial peptides. Drosomycins were tested against development of $P$. berghei ANKA gametocytes, with drosomycin-2 showing $30 \%$ inhibition at $20 \mu \mathrm{M}$, whereas prototype-peptide drosomycin showed over $70 \%$ inhibition at that same concentration (Tian et al., 2008).

The most interesting source of antimalarial AMP concerns insects that are themselves the vectors of parasitic diseases, like anopheline mosquitoes, responsible for malaria transmission. It seems logical that such insects need to be equipped with a considerable defense system against the parasites they carry. In Anopheles mosquitoes, there are different known protection mechanisms, such as (i) upregulation of NO synthase, (ii) melanotic encapsulation in refractory mosquitoes that inhibit parasite development (Collins etal., 1986; Vijay etal., 2011), and production of AMP that might play an important role in refractoriness. In the major vector of $P$. falciparum in subSaharan Africa, A. gambiae, defensin, cecropin, and gambicin AMP have been found (Vizioli et al., 2000; Blandin et al., 2002; Kim et al., 2004).

The A. gambiae cecropin gene is mainly expressed in the mosquito midgut in hemocyte-like cells, and its levels are significantly raised within $2 \mathrm{~h}$ of infection (Vizioli et al., 2000). The activity of the A. gambiae cecropin against Plasmodium was studied by creating transgenic mosquitoes with cecA expression under the control of the Aedes aegypti carboxypeptidase promotor. The number of oocysts was reduced by $60 \%$ compared to the non-transgenic mosquitoes (Kim et al., 2004).

Gambicin, extracted from two A. gambiae cell lines, is an immune-induced peptide predominantly expressed in the anterior midgut compartment, thorax, and abdomen. The mature gambicin peptide is active against Gram-positive and Gramnegative bacteria, filamentous fungi, and $P$. berghei ookinetes (Vizioli et al., 2001).

Other mosquito vectors, such as $A$. aegypti, responsible for transmission of dengue and yellow fever viruses, produce AMP with antimalarial activity. A. aegypti releases three 40-AA long defensins (Def A to C) and cecropin A in response to bacterial infections (Lowenberger et al., 1995, 1999). In transgenic A. aegypti mosquitoes with co-overexpression of $A$. aegypti cecropin A and defensin A, P. gallinaceum oocyst proliferation was significantly inhibited as compared to wildtype mosquitoes (Lowenberger, 2001; Kokoza et al., 2010). 
The strategy to produce transgenic mosquitoes that heterologously express AMP in order to interrupt Plasmodium transmission was also tested for scorpine, an AMP from the venom of Pandinus imperator scorpions. Scorpine belongs to a group of ion channel blockers with high activity against $P$. berghei ANKA gametes and ookinetes $\left(\mathrm{ED}_{50}\right.$ of 10 and $0.7 \mu \mathrm{M}$, respectively; Conde et al., 2000) that was shown to disrupt the sporogonic development of $P$. berghei. The scorpine gene was introduced into a vector for generation of transgenic flies resistant to infection by Plasmodia. The final aim of this work was to incorporate this gene under the promoter of proteolytic enzymes of the mosquito digestive tract, for synthesis and release of toxic peptide(s) into the stomach of freshly fed mosquitoes potentially carrying Plasmodium gametes; the presence of recombinant scorpine could be confirmed in transgenic A. gambiae cell supernatants (Possani et al., 2002). At low concentrations, recombinant scorpine reduced the number of ookinetes formed after mosquito feeding on $P$. berghei-infected mouse blood. Scorpine had highest effects (98\% inhibition) when added during gamete formation and fertilization (Carballar-Lejarazu et al., 2008). In view of this, strategies to deliver AMP into the mosquitoes to interrupt the sporogonic cycle are relevant; one such strategy has been reported that uses symbiotic bacteria that live in the mosquito's midgut: the transgenetic symbiont Pantoea agglomerans, expressing recombinant AMP Shiva-1 and scorpine, completely inhibited $P$. falciparum sporogonic cycle (Wang et al., 2012).

\section{Circular AMP with antimalarial properties}

There is a significant number of cyclic AMP and derived macrocycles that have shown antimalarial properties. The potentially large, but structurally often well-defined conformational space sampled, combined with the variety of AA, renders cyclic peptides ideally suited to interact with many receptors or to interfere with protein/protein interactions (Katoh et al., 2011; Giordanetto and Kihlberg, 2014). In this context, cyclosporin A (CsA, 1 in Figure 2) is a well-characterized immunosuppressant hydrophobic peptide (Borel et al., 1996) that was earlier found to have antimalarial activity against $P$. berghei and P. yoelii rodent malaria and on cultured P. berghei, P. falciparum, and P. vivax parasites (Nickell et al., 1982). More recently, nine CsA-resistant $P$. falciparum clones were isolated, of which three had lesions in cyclophilin genes and two in calcineurinsubunit genes (Kumar et al., 2005). The two cyclophilins affected had been identified as cyclosporin-binding proteins in $P$. falciparum (Gavigan etal., 2003), but CsA may also have other targets in Plasmodia, since, it has a number of different known targets including the mammalian P-glycoprotein transporter. In agreement with this hypothesis, sequence polymorphisms in (and possibly expression levels of) a $P$. falciparum P-glycoprotein homolog were found to affect susceptibility to CsA (Gavigan et al., 2007).

Thiostrepton (2 in Figure 2), a cyclic thiopeptide, has reported $\mathrm{IC}_{50}$ ranging from 1.8 to $17 \mu \mathrm{M}$ against parasite growth and protein synthesis of $P$. falciparum, though this is suggested to be an overestimate since solubility of the compound in culture medium is poor (Clough et al., 1997; McConkey et al., 1997). IC50 values for thiostrepton derivatives were $0.77 \mu \mathrm{M}$ and above against $P$. falciparum (Schoof et al., 2010), and other thiopeptides were described as displaying nanomolar $\mathrm{IC}_{50}$ against organellar protein synthesis in the same strain: micrococcin (3 nM), GE2270A (300 nM), and amythiamicin A (10 nM; Clough et al., 1999).

Most recently, three new macro-heterocyclic AMP, balgacyclamides A-C, were isolated from Microcystis aeruginosa EAWAG 251 and thoroughly characterized. Balgacyclamides A (3 in Figure 2) and B (4 in Figure 2) were evaluated for their antiparasitic activity and found to display micromolar $\mathrm{IC}_{50}$ activity against the chloroquine-resistant strain K1 of P. falciparum (9.0 and $8.2 \mu \mathrm{M}$, respectively) with good selectivity compared to their cytotoxicity (Portmann et al., 2014).

Another recent report on a cyclic antimalarial peptide concerns the Gly-rich cyclic octapeptide pohlianin C (5 in Figure 2), whose synthesis provided confirmation of the structure of this natural product. Evaluation against $P$. falciparum showed moderate antiplasmodial activity, consistent with data obtained from the natural sample. In addition, the synthesis of three analogs revealed that the antiplasmodial activity of pohlianin $\mathrm{C}$ can be preserved or increased with simplified structures (Lawer et al., 2014).

\section{Other synthetic antimalarial AMP: from NK-2 to IDR-1018}

NK-2 was one of the first synthetic AMP found to have antiparasitic properties. NK-2 is a shortened version of the mammalian protein NK-lysin, comprising its residues 39-65, and long known to display lytic activity against the fungal pathogen Candida albicans and a variety of Gram-positive and Gram-negative bacteria, while exhibits virtually no hemolytic or cytotoxic activity against human cells (Andrä and Leippe, 1999). In a study aimed at determining the antimicrobial spectrum of both NK-lysin and NK-2, activity against the protozoan parasite Trypanosoma cruzi was observed (Jacobs et al., 2003). Later, NK-2 was found to be hemolytic to PfRBC above $\sim 1 \mu \mathrm{M}$, while harmless for healthy RBC up to $10 \mu \mathrm{M}$, along with evidence that parasite membrane also suffered permeabilization at 5 and $10 \mu \mathrm{M}$. The selective lytic activity of NK-2 on PfRBC was further demonstrated by observation that fluorescently labeled NK-2 binds to infected erythrocytes and to parasites, but not to healthy erythrocytes (Gelhaus et al., 2008).

Another synthetic AMP with antimalarial activity is D-HALOrev. This design peptide possesses 26 AA with an even distribution of hydrophobic and charged residues, including nonproteinogenic ornithine (O, Orn), a Lys homolog. D-HALO-rev shows an $\mathrm{IC}_{50}$ value of $0.1 \mu \mathrm{M}$ against erythrocytic stages of $P$. falciparum, being able to penetrate PfRBC at sublytic concentrations and kill intraerythrocytic parasites (Mason et al., 2009). Similar results were obtained for an analog resulting from incorporation of Pro, Phe, and D-AA residues (D-Halo-P8F-rev), which showed reduced toxicity toward healthy RBC and fibroblasts (Mason et al., 2009).

A further step forward in this field was recent disclosure of the ability of synthetic peptide IDR-1018 to provide protection against cerebral malaria (Achtman et al., 2012). IDR-1018 is a 12-residue innate defense regulator analog of bactenecin, a cathelicidine from bovine neutrophils. It putatively owes its action to translocation across cell membrane and impairment of an intracellular target (Wieczorek et al., 2010). IDR-1018 was selected for 


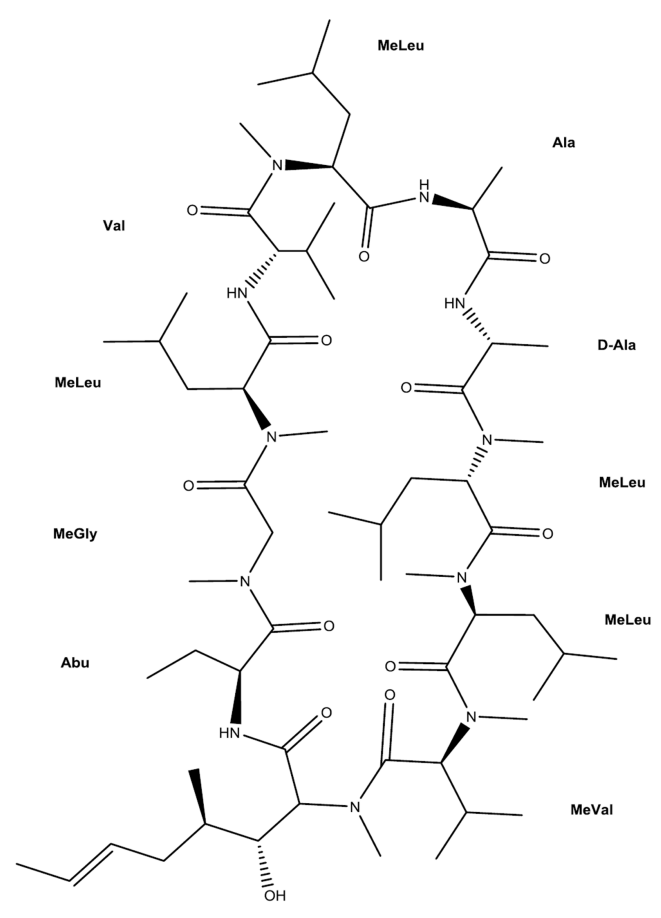

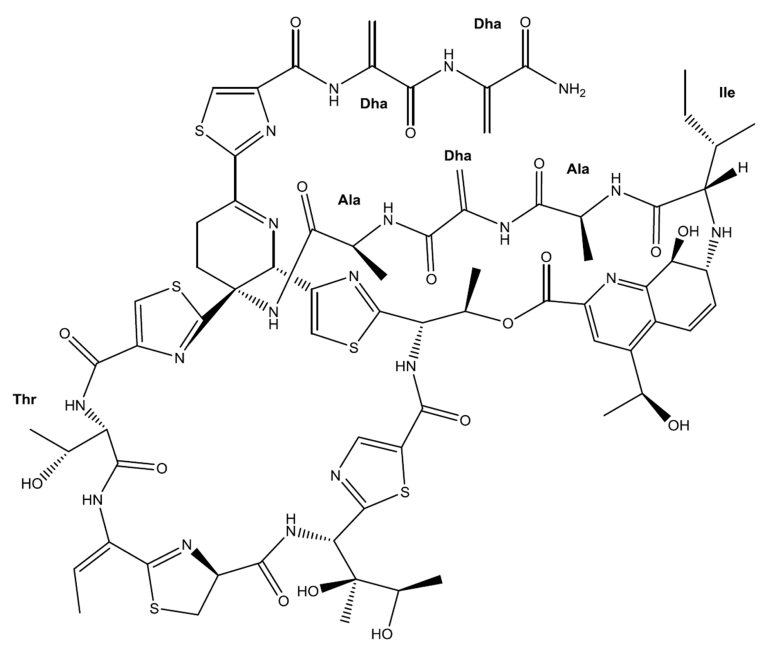

2

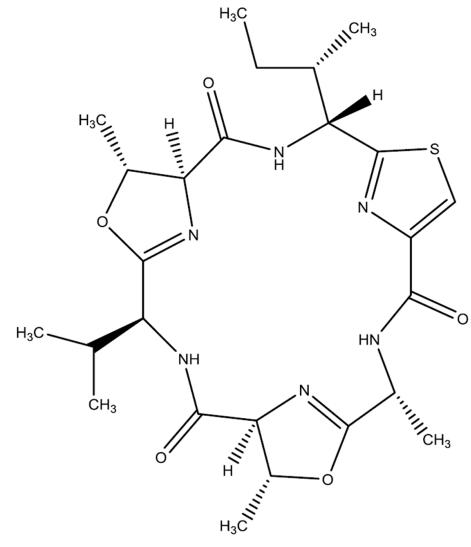

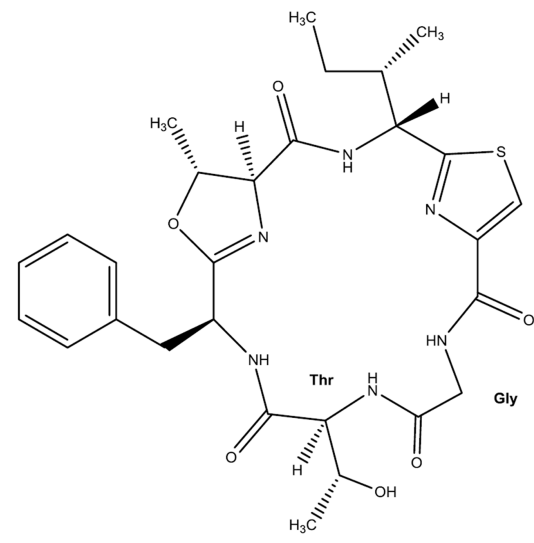

4

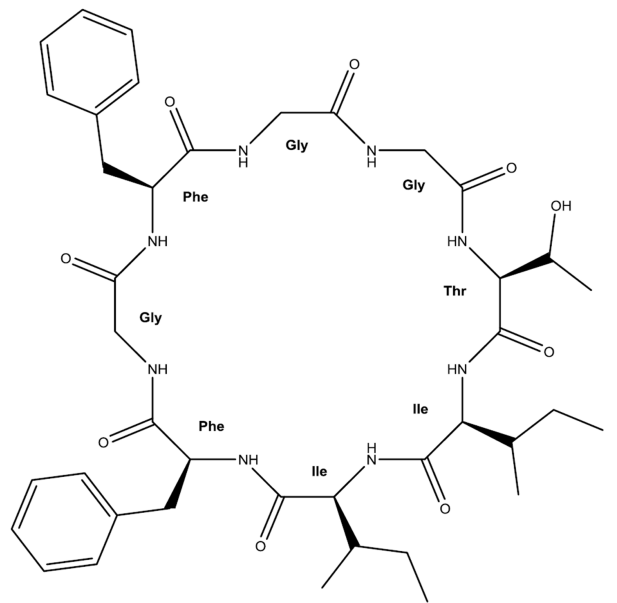

5

FIGURE 2 | Circular peptides with antimalarial activity. Full molecular structure is shown. Amino acid labeling, with the corresponding three-letter code, has been added where applicable: Abu, 2-aminobutyric acid; Ala, L-alanine; D-Ala, D-alanine; Dha, dehydroalanine; Gly, glycine; Ile,
L-isoleucine; Phe, L-phenylalanine; Thr, L-threonine; Val, L-valine; MeGly, $\mathrm{N}$-methylglycine [also known as sarcosine (Sar)]; MeLeu, N-methylleucine; MeVal, $N$-methylvaline. Uncommon amino acid residues or their analogs not possessing any internationally approved abbreviation were kept unlabeled. screening in cerebral malaria given its anti-inflammatory capabilities and low toxicity, and found to protect $56 \%$ of infected mice from cerebral malaria after prophylactic intravenous administration. When combined with the antimalarial pyrimethaminechloroquine medicine, IDR-1018 boosted protection from cerebral malaria in 41-68\% of infected mice (Achtman et al., 2012).
PROMISES AND PITFALLS OF PEPTIDE ANTIMALARIALS: FROM CONVENTIONAL PHARMACEUTICAL TO BIOTECHNOLOGICAL

\section{APPROACHES}

Examples of peptide drug candidates entering clinical trials remain scarce, as compared to those of small molecular drug candidates; despite a few such peptides display antimalarial activity (pexiganan 
in phase III, omiganan and OP-145 in phase 2, and NVB302 in phase I), their involvement in clinical trials is directed to disorders other than malaria (Fox, 2013). This is mainly due to the traditionally cautious attitude of pharma companies toward peptide-based drugs, given that:

- peptides seldom are orally bioavailable given their usually high molecular weight, extensive enzymatic degradation (proteolysis) and binding to plasma proteins;

- peptide production costs are high and synthesis scale-up is not easy, which will result in medicines too expensive, especially if targeted at low-income countries.

Therefore, until recent years, pharma companies have mostly put their bets on small drug candidates, with molecular weights tipically below $500 \mathrm{Da}$ and oral bioavailability, leaving much larger biomolecule-based candidates put aside, as molecules with over $5000 \mathrm{Da}$ are not orally bioavailable, among other limitations. However, small drugs often suffer from reduced selectivity, leading to unwanted off-target side effects; in turn, peptides and proteins are usually characterized by an extraordinary specificity for their targets, which may largely compensate for their low bioavailability, poor permeability and susceptibility to metabolic inactivation (Craik et al., 2013).

In the particular case of malaria, from World War II to the present, a huge plethora of small molecules nicely obeying the Lipinski's rule of 5 for orally bioavailable drugs (Lipinski et al., 1997) has been continuously feeding the antimalarial drug pipeline (Teixeira et al., 2014). Nonetheless, control of the disease remains out of reach, especially due to toxicity and resistance issues (Wells and Poll, 2010). Moreover, Lipinski's rule applies only to drug absorption by passive diffusion through cell membranes, i.e., it is not predictive for compounds actively transported by transmembranar proteins (Leeson, 2012). Altogether, this emphasizes the need for highly specific antimalarials, preferably with no or reduced propensity to elicit parasite resistance, and also that unconventional drugs, like peptides, may eventually fill such need, provided suitable strategies to overcome some challenges posed by peptide drugs are found. Fortunately, the 21 st century emerged along with the first evidences of a paradigm shift in this field: between 2011 and 2012, nineteen peptide drugs were approved in the US, and the remarkable expansion of peptide therapeutics development in the late 1990s and 2000s led to an unprecedented number of marketing approvals in 2012, while providing a robust pipeline that should deliver numerous approvals during the remainder of the 2010s; in the US, annual sales of peptide drugs exceed 13 bilion dollars, representing 1.5\% of global drug sales. In Europe, Germany and the UK account for $63 \%$ of the peptide therapeutics market, with France, Italy, Scandinavia, and Spain making up the rest of the major European salers in this area (Kaspar and Reichert, 2013).

In addition to the above, peptide and protein biotechnology continues evolving at full speed, with the most prominent example today being that of therapeutic antibodies (Leavy, 2010). Other biotechnological approaches include, e.g., bioactive peptide grafting onto suitable biocompatible carriers to enhance peptide bioavailability at the site of action (Costa etal., 2011; Lax and Meenan, 2012a,b; Maia et al., 2014), or development of long-acting release forms of peptides such as somatostatin analogs through encapsulation in biodegradable polymers requiring injection only at extended intervals to raise patient's compliance (Anthony and Freda, 2009). Genetic engineering and recombinant biotechnology are changing pharma's perspective toward peptide therapeutics, as genetically engineered proteins offered a window to previously untreatable medical conditions that convinced this industry to conform with the need to develop drugs that could not be administered through the oral route; it also motivated an intense search for alternative (to injection) drug delivery platforms to meet patient's acceptability, and offers an useful alternative to chemical production of large (>40 AA) peptides, whose synthesis is challenging and expensive, even at low scale; hence, recombinant biotechnology will play an increasingly important role in peptide manufacturing mainly due to quantity requirements (Lax, 2010). Still, biotechnology will complement, and not replace, chemical peptide synthesis in the production of peptide therapeutics: cost of large-scale peptide chemical synthesis, in particular through the most popular solid-phase procedures based on Fmoc-chemistry, has significantly decreased over the past 15 years, mainly due to technological evolution of automated synthesizers and chromatographic systems; moreover, many highly specific and potent peptide therapeutics require daily doses of only a few micrograms; furthermore, when applicable, chemical peptide synthesis is more easily scalable for manufacturing at up to a multi-10 $\mathrm{kg}$ or $100-\mathrm{kg}$ scale, and is less demanding in terms of process development, and less personnel intensive in terms of production, quality assurance and regulatory affairs; last, but not least, chemical approaches are far superior to biotechnological ones regarding flexibility in the design of analogs requiring unnatural amino acids or non-proteogenic building blocks (Lax, 2010).

In summary, peptide therapeutics are reaching a maturity level that emphasizes their potential interest against a wide diversity of medical challenges. While, about half of the peptides in clinical trials target indications in oncology, metabolic, cardiovascular and infectious diseases, the total range of therapeutic areas addressed encompasses a wide assortment of medical disorders from endocrinological lesions through to pain and hematology (Kaspar and Reichert, 2013). In the particular case of malaria, development of peptide therapeutics is still at its earliest infancy, but several cutting-edge approaches to antimalarial peptides are emerging today. One recent example followed demonstration that PfSERA5 plays an important role in parasite development; in this study, a number of peptides from the $N$ - and $C$-terminal regions of PfSERA5 active domain was synthesized and evaluated as antiplasmodials. These peptides reduced activity of the recombinant enzyme and co-localized with PfSERA5 within the parasite, thereby indicating the specific inhibition of PfSERA5 activity. Such results reinforce the role of PfSERA5 for the intraerythrocytic development of malaria parasites and unveil the relevance of this enzyme as target for new peptide antimalarials (Kanodia et al., 2014). In view of this, and considering the recent unveiling of the P. falciparum genome (Boddey et al., 2013), we can only expect the future to confirm that a new class of antimalarial drugs, based on AMP, will rise. 


\section{CONCLUDING REMARKS}

This review highlights that peptides are being put forward as one potential novel class of antimalarial drugs. A range of AMP exhibit antimalarial activity on malarial parasites in their blood or mosquito stages or both. Some peptides naturally occurring in mosquitoes affect the parasites transmitted by those insect vectors, but it has been difficult to determine the magnitude of their effects in the natural setting. However, this field of research is a recent one, and more systematic studies are needed to identify the structural variants that are most potent and selective on cultured parasites and to test them in vivo. Better understanding of mechanisms of action would help to guide the design of new peptides and the development of in vitro assays with which to compare their targetbinding affinities. Some antimalarial peptides are believed to act selectively on infected erythrocyte and/or intraerythrocytic parasite membranes, in which case the appropriate model membrane systems are required. This means that another well-known family of MAP, besides AMP, may soon gain also relevance in antimalarial approaches: that of CPP. These can translocate into cells without causing membrane damage, therefore being useful carriers for therapeutic cargoes to treat various conditions (De Figueiredo et al., 2014). Membrane-active AMP and CPP show significant similarities in charge, structure, and initial steps of interactions with membranes; moreover, CPP are being identified with antimalarial activity per se, e.g., TP10 that has broad-spectrum activity against both blood and mosquito stages of P. falciparum (Arrighi et al., 2008). In conclusion, MAP seem to be paving the way toward establishment of useful peptide-based drugs against parasitic infections.

\section{ACKNOWLEDGMENTS}

This work was mainly supported by FEDER funds through "Programa Operacional Factores de Competitividade" - COMPETE (ref. FCOMP-01-0124-FEDER-020963) and by Portuguese National funds through Fundação para a Ciência e a Tecnologia (ref. PTDC/QUI-QUI/116864/2010), with additional funding from FCT through strategic project PestC/QUI/UI0081/2013. Nuno Vale thanks FCT for post-doctoral grant SFRH/BPD/48345/2008.

\section{REFERENCES}

Achtman, A. H., Pilat, S., Law, C. W., Lynn, D. J., Janot, L., Mayer, M. L., et al. (2012). Effective adjunctive therapy by an innate defense regulatory peptide in a preclinical model of severe malaria. Sci. Transl. Med. 4, 135ra164. doi: 10.1126/scitranslmed.3003515

Agerberth, B., Charo, J., Werr, J., Olsson, B., Idali, F., Lindbom, L., et al. (2000). The human antimicrobial and chemotactic peptides ll-37 and alpha-defensins are expressed by specific lymphocyte and monocyte populations. Blood 96, 30863093.

Andrä, J., and Leippe, M. (1999). Candidacidal activity of shortened synthetic analogs of amoebapores and NK-lysin. Med. Microbiol. Immunol. 188, 117-124. doi: $10.1007 / \mathrm{s} 004300050113$

Anthony, L., and Freda, P. U. (2009). From somatostatin to octreotide LAR: evolution of a somatostatin analogue. Curr. Med. Res. Opin. 25, 2989-2999. doi: 10.1185/03007990903328959

Arrighi, R. B., Ebikeme, C., Jiang, Y., Ranford-Cartwright, L., Barrett, M. P., Langel, U., et al. (2008). Cell-penetrating peptide TP10 shows broadspectrum activity against both Plasmodium falciparum and Trypanosoma bruce brucei. Antimicrob. Agents Chemother. 52, 3414-3417. doi: 10.1128/AAC. 01450-07
Arrighi, R. B., Nakamura, C., Miyake, J., Hurd, H., and Burgess, J. G. (2002). Design and activity of antimicrobial peptides against sporogonic-stage parasites causing murine malarias. Antimicrob. Agents Chemother. 46, 2104-2110. doi: 10.1128/AAC.46.7.2104-2110.2002

Bals, R., Wang, X., Zasloff, M., and Wilson, J. M. (1998). The peptide antibiotic ll-37/hcap-18 is expressed in epithelia of the human lung where it has broad antimicrobial activity at the airway surface. Proc. Natl. Acad. Sci. U.S.A. 95, 9541-9546. doi: 10.1073/pnas.95.16.9541

Bastos, M., Bai, G., Gomes, P., Andreu, D., Goormaghtigh, E., and Prieto, M. (2008). Energetics and partition of two cecropin-melittin hybrid peptides to model membranes of different composition. Biophys. J. 94, 2128-2141. doi: 10.1529/biophysj.107.119032

Bechinger, B. (1996). Towards membrane protein design: $\mathrm{pH}$ dependent topology of histidine-containing polypeptides. J. Mol. Biol. 263, 768-775. doi: 10.1006/jmbi.1996.0614

Becker, K., Tilley, L., Vennerstrom, J. L., Roberts, D., Rogerson, S., and Ginsburg, H. (2004). Oxidative stress in malaria parasite-infected erythrocytes: hostparasite interactions. Int. J. Parasitol. 34, 163-189. doi: 10.1016/j.ijpara.2003. 09.011

Beevers, A. J., and Dixon, A. M. (2010). Helical membrane peptides to modulate cell function. Chem. Soc. Rev. 39, 2146-2157. doi: 10.1039/ b912944h

Bell, A. (2011). Antimalarial peptides: the long and the short of it. Curr. Pharm. Des. 17, 2719-2731. doi: 10.2174/138161211797416057

Bell, A., Monaghan, P., and Page, A. P. (2006). Peptidyl-prolyl cis-trans isomerases (immunophilins) and their roles in parasite biochemistry, host-parasite interaction and antiparasitic drug action. Int. J. Parasitol. 36, 261-276. doi: 10.1016/j.ijpara.2005.11.003

Bellamy, W., Takase, M., Yamauchi, K., Wakabayashi, H., Kawase, K., and Tomita, M. (1992). Identification of the bactericidal domain of lactoferrin. Biochim. Biophys. Acta 1121, 130-136. doi: 10.1016/0167-4838(92)90346-F

Biagini, G. A., O’Neill, P. M., Nzila, A., Ward, S. A., and Bray, P. G. (2003). Antimalarial chemotherapy: young guns or back to the future? Trends Parasitol. 19, 479-487. doi: 10.1016/j.pt.2003.09.011

Blackman, M. J. (2004). Proteases in host cell invasion by the malaria parasite. Cell. Microbiol. 6, 893-903. doi: 10.1111/j.1462-5822.2004.00437.x

Blandin, S., Moita, L. F., Kocher, T., Wilm, M., Kafatos, F. C., and Levashina, E. A. (2002). Reverse genetics in the mosquito Anopheles gambiae: targeted disruption of the defensin gene. EMBO Rep. 3, 852-856. doi: 10.1093/embo-reports/ kvf180

Boddey, J. A., Carvalho, T. G., Hodder, A. N., Sargeant, T. J., Sleebs, B. E., Marapana, D., et al. (2013). Role of Plasmepsin V in export of diverse protein families from the Plasmodium falciparum exportome. Traffic 14, 532-550. doi: $10.1111 /$ tra. 12053

Boman, H. G. (2003). Antibacterial peptides: basic facts and emerging concepts. J. Intern. Med. 254, 197-215. doi: 10.1046/j.1365-2796.2003.01228.x

Boman, H. G., Wade, D., Boman, I. A., Wahlin, B., and Merrifield, R. B. (1989). Antibacterial and antimalarial properties of peptides that are cecropin-melittin hybrids. FEBS Lett. 259, 103-106. doi: 10.1016/0014-5793(89) 81505-4

Borel, J. F., Baumann, G., Chapman, I., Donatsch, P., Fahr, A., Mueller, E. A., et al. (1996). In vivo pharmacological effects of ciclosporin and some analogues. $A d v$. Pharmacol. 35, 115-246. doi: 10.1016/S1054-3589(08)60276-8

Bruston, F., Lacombe, C., Zimmermann, K., Piesse, C., Nicolas, P., and El Amri, C. (2007). Structural malleability of plasticins: preorganized conformations in solution and relevance for antimicrobial activity. Biopolymers 86, 42-56. doi: 10.1002/bip.20703

Bulet, P., Hetru, C., Dimarcq, J. L., and Hoffmann, D. (1999). Antimicrobial peptides in insects; structure and function. Dev. Comp. Immunol. 23, 329-344. doi: 10.1016/S0145-305X(99)00015-4

Carballar-Lejarazu, R., Rodriguez, M. H., de la Cruz Hernandez-Hernandez, F., Ramos-Castaneda, J., Possani, L. D., Zurita-Ortega, M., et al. (2008). Recombinant scorpine: a multifunctional antimicrobial peptide with activity against different pathogens. Cell. Mol. Life Sci. 65, 3081-3092. doi: 10.1007/s00018-008-8250-8

Carlsson, A., Engstrom, P., Palva, E. T., and Bennich, H. (1991). Attacin, an antibacterial protein from Hyalophora cecropia, inhibits synthesis of outer membrane proteins in Escherichia coli by interfering with omp gene transcription. Infect. Immun. 59, 3040-3045. 
Carlsson, A., Nystrom, T., de Cock, H., and Bennich, H. (1998). Attacin - an insect immune protein-binds lps and triggers the specific inhibition of bacterial outer-membrane protein synthesis. Microbiology 144, 2179-2188. doi: 10.1099/00221287-144-8-2179

Carter, V., Underhill, A., Baber, I., Sylla, L., Baby, M., Larget-Thiery, I., et al (2013). Killer bee molecules: antimicrobial peptides as effector molecules to target sporogonic stages of Plasmodium. PLoS Pathog. 9:e1003790. doi: 10.1371/journal.ppat.1003790

Castle, M., Nazarian, A., Yi, S. S., and Tempst, P. (1999). Lethal effects of apidaecin on Escherichia coli involve sequential molecular interactions with diverse targets. J. Biol. Chem. 274, 32555-32564. doi: 10.1074/jbc.274.46.32555

Christensen, B., Fink, J., Merrifield, R. B., and Mauzerall, D. (1988). Channelforming properties of cecropins and related model compounds incorporated into planar lipid membranes. Proc. Natl. Acad. Sci. U.S.A. 85, 5072-5076. doi: 10.1073/pnas.85.14.5072

Clough, B., Rangachari, K., Strath, M., Preiser, P. R., and Wilson, R. J. (1999) Antibiotic inhibitors of organellar protein synthesis in Plasmodium falciparum. Protist 150, 189-195. doi: 10.1016/S1434-4610(99)70021-0

Clough, B., Strath, M., Preiser, P., Denny, P., and Wilson, I. R. (1997). Thiostrepton binds to malarial plastid rRNA. FEBS Lett. 406, 123-125. doi: 10.1016/S00145793(97)00241-X

Collins, F. H., Sakai, R. K., Vernick, K. D., Paskewitz, S., Seeley, D. C., Miller, L. H., et al. (1986). Genetic selection of a Plasmodium-refractory strain of the malaria vector Anopheles gambiae. Science 234, 607-610. doi: 10.1126/science.3532325

Conde, R., Zamudio, F. Z., Rodriguez, M. H., and Possani, L. D. (2000). Scorpine, an anti-malaria and anti-bacterial agent purified from scorpion venom. FEBS Lett. 471, 165-168. doi: 10.1016/S0014-5793(00)01384-3

Costa, F., Carvalho, I. F., Montelaro, R. C., Gomes, P., and Martins, M. C. (2011) Covalent immobilization of Antimicrobial Peptides (AMPs) onto biomaterial surfaces. Acta Biomater. 7, 1431-1440. doi: 10.1016/j.actbio.2010.11.005

Cotter, P. D., Ross, R. P., and Hill, C. (2013). Bacteriocins - a viable alternative to antibiotics? Nat. Rev. Microbiol. 11, 95-105. doi: 10.1038/ nrmicro2937

Craik, D. J., and Conibear, A. C. (2011). The chemistry of cyclotides. J. Org. Chem. 76, 4805-4817. doi: 10.1021/jo200520v

Craik, D. J., Daly, N. L., Bond, T., and Waine, C. (1999). Plant cyclotides: a unique family of cyclic and knotted proteins that defines the cyclic cystine knot structural motif. J. Mol. Biol. 294, 1327-1336. doi: 10.1006/jmbi.1999.3383

Craik, D. J., Fairlie, D. P., Liras, S., and Price, D. (2013). The future of peptide-based drugs. Chem. Biol. Drug Des. 81, 136-147. doi: 10.1111/cbdd. 12055

Dagan, A., Efron, L., Gaidukov, L., Mor, A., and Ginsburg, H. (2002). In Vitro Antiplasmodium effects of dermaseptin S4 derivatives. Antimicrob. Agents Chemother. 46, 1059-1066. doi: 10.1128/AAC.46.4.1059-1066.2002

De Figueiredo, I. R., Freire, J. M., Flores, L., Veiga, A. S., and Castanho, M. A. (2014) Cell-penetrating peptides: a tool for effective delivery in gene-targeted therapies. IUBMB Life 66, 182-194. doi: 10.1002/iub.1257

Dhawan, S., Dua, M., Chishti, A. H., and Hanspal, M. (2003). Ankyrin peptide blocks falcipain-2-mediated malaria parasite release from red blood cells. J. Biol. Chem. 278, 30180-30186. doi: 10.1074/jbc.M305132200

Dixon, M. W., Thompson, J., Gardiner, D. L., and Trenholme, K. R. (2008). Sex in plasmodium: a sign of commitment. Trends Parasitol. 24, 168-175. doi: 10.1016/j.pt.2008.01.004

Dondorp, A. M., Nosten, F., Yi, P., Das, D., Phyo, A. P., Tarning, J., et al. (2009) Artemisinin resistance in Plasmodium falciparum malaria. N. Engl. J. Med. 361 455-467. doi: 10.1056/NEJMoa0808859

Eckstein-Ludwig, U., Webb, R. J., Van Goethem, I. D., East, J. M., Lee, A. G., Kimura M., etal. (2003). Artemisinins target the SERCA of Plasmodium falciparum. Nature 424, 957-961. doi: 10.1038/nature01813

Efimova, S. S., Schagina, L. V., and Ostroumova, O. S. (2014). Channel-forming activity of cecropins in lipid bilayers: effect of agents modifying the membrane dipole potential. Langmuir 30, 7884-7892. doi: 10.1021/la501549v

Efron, L., Dagan, A., Gaidukov, L., Ginsburg, H., and Mor, A. (2002). Direct interaction of dermaseptin S4 aminoheptanoyl derivative with intraerythrocytic malaria parasite leading to increased specific antiparasitic activity in culture. J. Biol. Chem. 277, 24067-24072. doi: 10.1074/jbc.M202089200

Ekengren, S., and Hultmark, D. (1999). Drosophila cecropin as an antifungal agent. Insect Biochem. Mol. Biol. 29, 965-972. doi: 10.1016/S0965-1748(99)00071-5
Fjell, C. D., Hiss, J. A., Hancock, R. E., and Schneider, G. (2011). Designing antimicrobial peptides: form follows function. Nat. Rev. Drug Discov. 11, 37-51. doi: $10.1038 / \mathrm{nrd} 3591$

Flannery, E. L., Chatterjee, A. K., and Winzeler, E. A. (2013). Antimalarial drug discovery - approaches and progress towards new medicines. Nat. Rev. Microbiol. 11, 849-862. doi: 10.1038/nrmicro3138

Fox, J. L. (2013). Antimicrobial peptides stage a comeback. Nat. Biotechnol. 31, 379-382. doi: 10.1038/nbt.2572

Frederik, P. M., Stuart, M. C., Bomans, P. H., and Busing, W. M. (1989). Phospholipid, nature's own slide and cover slip for cryo-electron microscopy. J. Microsc. 153, 81-92. doi: 10.1111/j.1365-2818.1989.tb01469.x

Ganz, T., and Weiss, J. (1997). Antimicrobial peptides of phagocytes and epithelia. Semin. Hematol. 34, 343-354.

Gavigan, C. S., Kiely, S. P., Hirtzlin, J., and Bell, A. (2003). Cyclosporinbinding proteins of Plasmodium falciparum. Int. J. Parasitol. 33, 987-996. doi: 10.1016/S0020-7519(03)00125-5

Gavigan, C. S., Shen, M., Machado, S. G., and Bell, A. (2007). Influence of the Plasmodium falciparum P-glycoprotein homologue 1 (pfmdr1 gene product) on the antimalarial action of cyclosporin. J. Antimicrob. Chemother. 59, 197-203. doi: $10.1093 / \mathrm{jac} / \mathrm{dkl} 461$

Ge, Y., MacDonald, D. L., Holroyd, K. J., Thornsberry, C., Wexler, H., and Zasloff, M. (1999). In vitro antibacterial properties of pexiganan, an analog of magainin. Antimicrob. Agents Chemother. 43, 782-788.

Gelhaus, C., Jacobs, T., Andra, J., and Leippe, M. (2008). The antimicrobial peptide NK-2, the core region of mammalian nk-lysin, kills intraerythrocytic Plasmodium falciparum. Antimicrob. Agents Chemother. 52, 1713-1720. doi: 10.1128/AAC.01342-07

Ghosh, J. K., Shaool, D., Guillaud, P., Ciceroni, L., Mazieri, D., Kustanovich, I., et al. (1997). Selective cytotoxicity of dermaseptin S3 toward intraerythrocytic Plasmodium falciparum and the underlying molecular basis. J. Biol. Chem. 272, 31609-31616. doi: 10.1074/jbc.272.50.31609

Giordanetto, F., and Kihlberg, J. (2014). Macrocyclic drugs and clinical candidates: what can medicinal chemists learn from their properties? J. Med. Chem. 57, 278-295. doi: 10.1021/jm400887j

González, C., Langdon, G. M., Bruix, M., Gálvez, A., Valdivia, E., Maqueda, M., et al. (2000). Bacteriocin AS-48, a microbial cyclic polypeptide structurally and functionally related to mammalian NK-lysin. Proc. Natl. Acad. Sci. U.S.A. 97, 11221-11226. doi: 10.1073/pnas.210301097

Gwadz, R. W., Kaslow, D., Lee, J. Y., Maloy, W. L., Zasloff, M., and Miller, L. H. (1989). Effects of magainins and cecropins on the sporogonic development of malaria parasites in mosquitos. Infect. Immun. 57, 2628-2633.

Haney, E. F., and Hancock, R. E. W. (2013). Peptide design for antimicrobial and immunomodulatory applications. Biopolymers 100, 572-583. doi: 10.1002/bip. 22250

Hsiao, L. L., Howard, R. J., Aikawa, M., and Taraschi, T. F. (1991). Modification of host cell membrane lipid composition by the intra-erythrocytic human malaria parasite Plasmodium falciparum. Biochem. J. 274, 121-132.

Hsu, C. H., Chen, C., Jou, M. L., Lee, A. Y., Lin, Y. C., Yu, Y. P., et al. (2005). Structural and DNA-binding studies on the bovine antimicrobial peptide, indolicidin: evidence for multiple conformations involved in binding to membranes and DNA. Nucleic Acids Res. 33, 4053-4064. doi: 10.1093/nar/gki725

Jacobs, T., Bruhn, H., Gaworski, I., Fleischer, B., and Leippe, M. (2003). NK-lysin and its shortened analog NK-2 exhibit potent activities against Trypanosoma cruzi. Antimicrob. Agents Chemother. 47, 607-613. doi: 10.1128/AAC.47.2.607-613.2003

Jagadish, K., and Camarero, J. A. (2010). Cyclotides: a promising scaffold for peptidebased therapeutics. Biopolymers 94, 611-616. doi: 10.1002/bip.21433

Jaynes, J. M., Burton, C. A., Barr, S. B., Jeffers, G. W., Julian, G. R., White, K. L., et al. (1988). In vitro cytocidal effect of novel lytic peptides on Plasmodium falciparum and Trypanosoma cruzi. FASEB J. 2, 2878-2883.

Jeu, L., and Fung, H. B. (2004). Daptomycin: a cyclic lipopeptide antimicrobial agent. Clin. Ther. 2, 1728-1757. doi: 10.1016/j.clinthera.2004.11.014

Kanodia, S., Kumar, G., Rizzi, L., Pedretti, A., Hodder, A. N., Romeo, S., et al. (2014). Synthetic peptides derived from the C-terminal $6 \mathrm{kDa}$ region of Plasmodium falciparum SERA5 inhibit the enzyme activity and malaria parasite development. Biochim. Biophys. Acta 1840, 2765-2775. doi: 10.1016/j.bbagen.2014.04.013

Kaspar, A. A., and Reichert, J. M. (2013). Future directions for peptide therapeutics developments. Drug Discov. Today 18, 807-817. doi: 10.1016/j.drudis.2013.05.011 
Katoh, T., Goto, Y., Reza, M. S., and Suga, H. (2011). Ribosomal synthesis of backbone macrocyclic peptides. Chem. Commun. 47, 9946-9958. doi: $10.1039 / \mathrm{clcc} 12647 \mathrm{~d}$

Kim, W., Koo, H., Richman, A. M., Seeley, D., Vizioli, J., Klocko, A. D., et al. (2004). Ectopic expression of a cecropin transgene in the human malaria vector mosquito Anopheles gambiae (diptera: Culicidae): effects on susceptibility to Plasmodium J. Med. Entomol. 41, 447-455. doi: 10.1603/0022-2585-41.3.447

Klein, E. Y. (2013). Antimalarial drug resistance: a review of the biology and strategies to delay emergence and spread. Int. J. Antimicrob. Agents 41, 311-317. doi 10.1016/j.ijantimicag.2012.12.007

Kokoza, V., Ahmed, A., Shin, S. W., Okafor, N., Zou, Z., and Raikhel, A. S. (2010) Blocking of Plasmodium transmission by cooperative action of cecropin a and defensin a in transgenic Aedes aegypti mosquitoes. Proc. Natl. Acad. Sci. U.S.A. 107, 8111-8116. doi: 10.1073/pnas.1003056107

Krugliak, M., Feder, R., Zolotarev, V., Gaidukov, L., Dagan, A., Ginsburg, H., et al. (2000). Antimalarial activities of dermaseptin S4 derivatives. Antimicrob. Agents Chemother. 44, 2442-2451. doi: 10.1128/AAC.44.9.2442-2451.2000

Kückelhaus, S. A. S., Leite, J. R., Muniz-Junqueira, M. I., Sampaio, R. N., Bloch, C. Jr., and Tosta, C. E. (2009). Antiplasmodial and antileishmanial activities of phylloseptin-1, an antimicrobial peptide from the skin secretion of Phyllomedusa azurea (Amphibia). Exp. Parasitol. 123, 11-16. doi: 10.1016/j.exppara.2009.05.002

Kumar, R., Musiyenko, A., and Barik, S. (2005). Plasmodium falciparum calcineurin and its association with heat shock protein 90: mechanisms for the antimalarial activity of cyclosporin A and synergism with geldanamycin. Mol. Biochem. Parasitol. 141, 29-37. doi: 10.1016/j.molbiopara.2005.01.012

Kuroda, K., and Gaputo, G. A. (2013). Antimicrobial polymers as synthetic mimics of host-defense peptides. Wiley Interdiscip. Rev. Nanomed. Nanobitechnol. 5 49-66. doi: 10.1002/wnan.1199

Ladokhin, A. S., and White, S. H. (2001). Protein chemistry at membrane interfaces: non-additivity of electrostatic and hydrophobic interactions. J. Mol. Biol. 309, 543-552. doi: 10.1006/jmbi.2001.4684

Lawer, A., Tai, J., Jolliffe, K. A., Fletcher, S., Avery, V. M., and Hunter, L. (2014). Total synthesis and antiplasmodial activity of pohlianin $\mathrm{C}$ and analogues. Bioorg. Med. Chem. Lett. 24, 2645-2647. doi: 10.1016/j.bmcl.2014.04.071

Lawyer, C., Pai, S., Watabe, M., Borgia, P., Mashimo, T., Eagleton, L., et al. (1996) Antimicrobial activity of a 13 amino acid tryptophan-rich peptide derived from a putative porcine precursor protein of a novel family of antibacterial peptides. FEBS Lett. 390, 95-98. doi: 10.1016/0014-5793(96)00637-0

Lax, R. (2010). The Future of Peptide Development in the Pharmaceutical Industry, Pharmanuacturing: the International Peptide Review. Available at: http://www.polypeptide.com/web/upload/medias/1401702726538c49464a6f5 .pdf (assessed November 21, 2014).

Lax, R., and Meenan, C. (2012a). Challenges for Therapeutic Peptides Part 1: On the Inside, Looking Out, Innovations in Pharmaceutical Technology. Available at: http://www.polypeptide.com/web/upload/medias/1401702387538c47f367ccc .pdf (assessed November 21, 2014).

Lax, R., and Meenan, C. (2012b). Challenges for Therapeutic Peptides Part 2: Delivery Systems, Innovations in Pharmaceutical Technology. Available at: http://www.polypeptide.com/web/upload/medias/1401702335538c47bf450c4 .pdf (assessed November 21, 2014).

Leavy, O. (2010). Therapeutic antibodies: past, present and future. Nat. Rev. Immunol. 10, 297. doi: 10.1038/nri2763

Leeson, P. (2012). Drug discovery: chemical beauty contest. Nature 481, 455-456. doi: $10.1038 / 481455$ a

Lehrer, R., Barton, A., Daher, K. A., Harwig, S. S. L., Ganz, T., and Selsted, M. E. (1989). Interaction of human defensins with Escherichia coli. J. Clin. Invest. 84, 553-561. doi: 10.1172/JCI114198

Lehrer, R. I., Cole, A. M., and Selsted, M. E. (2012). $\theta$-defensins: cyclic peptides with endless potential. J. Biol. Chem. 287, 27014-27019. doi: 10.1074/jbc.R112. 346098

Li, W. F., Ma, G. X., and Zhou, X. X. (2006). Apidaecin-type peptides: biodiversity, structure-function relationships and mode of action. Peptides 27, 2350-2359. doi: 10.1016/j.peptides.2006.03.016

Lipinski, C. A., Lombardo, F., Dominy, B. W., and Feeney, P. J. (1997). Experimental and computational approaches to estimate solubility and permeability in drug discovery and development settings. Adv. Drug Deliv. Rev. 23, 3-25. doi: 10.1016/S0169-409X(96)00423-1
López-Rojas, R., Docobo-Pérez, F., Pachón-Ibáñez, M., De La Torre, B. G., Fernández-Reyes, M., March, C., et al. (2011). Efficacy of cecropin A-melittin peptides on a sepsis model of infection by pan-resistant Acinetobacter baumannii. Eur. J. Clin. Microbiol. Infect. Dis. 11, 1391-1398. doi: 10.1007/s10096-011-1233-y Lowenberger, C. (2001). Innate immune response of Aedes aegypti. Insect Biochem. Mol. Biol. 31, 219-229. doi: 10.1016/S0965-1748(00)00141-7

Lowenberger, C., Bulet, P., Charlet, M., Hetru, C., Hodgeman, B., Christensen, B. M., et al. (1995). Insect immunity: isolation of 3 novel inducible antibacterial defensins from the vector mosquito, Aedes aegypti. Insect Biochem. Mol. 25, 867873. doi: 10.1016/0965-1748(95)00043-U

Lowenberger, C., Charlet, M., Vizioli, J., Kamal, S., Richman, A., Christensen, B. M., et al. (1999). Antimicrobial activity spectrum, cDNA cloning, and mRNA expression of a newly isolated member of the cecropin family from the mosquito vector Aedes aegypti. J. Biol. Chem. 274, 20092-20097. doi: 10.1074/jbc.274.29.20092

Ludtke, S. J., He, K., Heller, W. T., Harroun, T. A., Yang, L., and Huang, H. W. (1996). Membrane pores induced by magainin. Biochemistry 35, 13723-13728. doi: 10.1021/bi9620621

Maia, F. R., Barbosa, M., Gomes, D. B., Vale, N., Granja, P., Gomes, P., et al. (2014). Hydrogel depots for local co-delivery of osteoinductive peptides and mesenchymal stem cells. J. Control. Release 189, 158-168. doi: 10.1016/j.jconrel.2014.06.030

Malpede, B. M., and Tolia, N. H. (2014). Malaria adhesins: structure and function. Cell. Microbiol. 16, 621-631. doi: 10.1111/cmi.12276

Mantel, P.-Y., Hoang, A. N., Goldowitz, I., Potashnikova, D., Hamza, B., Vorobjev, I., et al. (2013). Malaria-infected erythrocyte-derived microvesicles mediate cellular communication within the parasite population and with the host immune system. Cell Host Microbe 13, 521-534. doi: 10.1016/j.chom.2013.04.009

Mason, A. J., Moussaoui, W., Abdelrahman, T., Boukhari, A., Bertani, P., Marquette, A., et al. (2009). Structural determinants of antimicrobial and antiplasmodial activity and selectivity in histidine-rich amphipathic cationic peptides. J. Biol. Chem. 284, 119-133. doi: 10.1074/jbc.M806201200

Matsuda, S., and Koyasu, S. (2000). Mechanisms of action of cyclosporin. Immunopharmacology 47, 119-125. doi: 10.1016/S0162-3109(00)00192-2

McConkey, G. A., Rogers, M. J., and McCutchan, T. F. (1997). Inhibition of Plasmodium falciparum protein synthesis. Targeting the plastid like organelle with thiostrepton. J. Biol. Chem. 272, 2046-2049. doi: 10.1074/jbc.272.4.2046

Melo, M. N., Ferre, R., and Castanho, M. A. (2009). Antimicrobial peptides: linking partition, activity and high membrane-bound concentrations. Nat. Rev. Microbiol. 7, 245-250. doi: 10.1038/nrmicro2095

Nickell, S. P., Scheibel, L. W., and Cole, G. A. (1982). Inhibition by cyclosporin A of rodent malaria in vivo and human malaria in vitro. Infect. Immun. 37, 1093-1100.

Otvos, L. Jr. (2005). Antibacterial peptides and proteins with multiple cellular targets. J. Pept. Sci. 11, 697-706. doi: 10.1002/psc.698

Pelegrini, P., Sarto, R., Silva, O., Franco, O. L., and Grossi-de-Sa, M. F. (2011). Antibacterial peptides from plants: what they are and how they probably work. Biochem. Res. Int. 2011, 1-9. doi: 10.1155/2011/250349

Philips, R. S. (2001). Current status of malaria and potential for control. Clin. Microbiol. Rev. 14, 208-226. doi: 10.1128/CMR.14.1.208-226.2001

Portmann, C., Sieber, S., Wirthensohn, S., Blom, J. F., Da Silva, L., Baudat, E., et al. (2014). Balgacyclamides, antiplasmodial heterocyclic peptides from Microcystis aeruguinosa EAWAG 251. J. Nat. Prod. 77, 557-562. doi: 10.1021/np400814w

Possani, L. D., Corona, M., Zurita, M., and Rodríguez, M. H. (2002). From noxiustoxin to scorpine and possible transgenic mosquitoes resistant to malaria. Arch. Med. Res. 33, 398-404. doi: 10.1016/S0188-4409(02)00370-3

Pouny, Y., Rapaport, D., Mor, A., Nicolas, P., and Shai, Y. (1992). Interaction of antimicrobial dermaseptin and its fluorescently labeled analogues with phospholipid membranes. Biochemistry 31, 12416-12423. doi: 10.1021/bi00164a017

Powers, J.-P. S., and Hancock, R. E. W. (2003). The relationship between peptide structure and antibacterial activity. Peptides 24, 1681-1691. doi: 10.1016/j.peptides.2003.08.023

Pretzel, J., Mohring, F., Rahlfs, S., and Becker, K. (2013). Antiparasitic peptides. $A d v$ Biochem. Eng. Biotechnol. 135, 157-192. doi: 10.1007/10_2013_191

Prudêncio, M., Rodriguez, A., and Mota, M. M. (2006). The silent path to thousands of merozoites: the Plasmodium liver stage. Nat. Rev. Microbiol. 4, 849-856. doi: $10.1038 /$ nrmicro 1529

Pushpanathan, M., Gunasekaran, P., and Rajendhran, J. (2013). Antimicrobial peptides: versatile biological properties. Int. J. Pept. 2013:675391. doi: $10.1155 / 2013 / 675391$ 
Raghuraman, H., and Chattopadhyay, A. (2007). Melittin: a membrane-active peptide with diverse functions. Biosci. Rep. 27, 189-223. doi: 10.1007/s10540006-9030-z

Regev-Rudzki, N., Wilson, D. W., Carvalho, T. G., Sisquella, X., Coleman, B. M., Rug, M., etal. (2013). Cell-cell communication between malariainfected red blood cells via exosome-like vesicles. Cell 153, 1120-1133. doi: 10.1016/j.cell.2013.04.029

Robert, A., Dechy-Cabaret, O., Cazelles, J., and Meunier, B. (2002). From mechanistic studies on artemisinin derivatives to new modular antimalarial drugs. Acc. Chem. Res. 35, 167-174. doi: 10.1021/ar990164o

Rodriguez, M. D. C., Zamudio, F., Torres, J. A., Gonzalez-Ceron, L., Possani, L. D., and Rodriguez, M. H. (1995). Effect of a cecropin-like synthetic ppetide (Shiva-3) on the sporogonic development of Plasmodium berghei. Exp. Parasitol. 80, 596-604. doi: 10.1006/expr.1995.1075

Rotem, S., and Mor, A. (2009). Antimicrobial peptide mimics for improved therapeutic properties. Biochim. Biophys. Acta 1788, 1582-1592. doi: 10.1016/j.bbamem.2008.10.020

Schoof, S., Pradel, G., Aminake, M. N., Ellinger, B., Baumann, S., Potowski, M., et al. (2010). Antiplasmodial thiostrepton derivatives: proteasome inhibitors with a dual mode of action. Angew. Chem. Int. Ed. Engl. 49, 3317-3321. doi: 10.1002/anie. 200906988

Selsted, M. E., Harwig, S. S., Ganz, T., Schilling, J. W., and Lehrer, R. I. (1985). Primary structures of three human neutrophil defensins. J. Clin. Invest. 76, 14361439. doi: 10.1172/JCI112121

Sgolastra, F., Deronde, B. M., Sarapas, J. M., Som, A., and Tew, G. N. (2013). Designing mimics of membrane active proteins. Acc. Chem. Res. 46, 2977-2987. doi: 10.1021/ar400066v

Simmaco, M., Mignogna, G., and Barra, D. (1999). Antimicrobial peptides from amphibian skin: what do they tell us? Biopolymers 47, 435-450. doi: 10.1002/(SICI) 1097-0282 (1998)47:6<435::AID-BIP3>3.0.CO;2-8

Singh, B., and Daneshvar, C. (2013). Human infections and detection of Plasmodium knowlesi. Clin. Microbiol. Rev. 26, 165-184. doi: 10.1128/CMR.00079-12

Som, A., Vemparala, S., Ivanov, I., and Tew, G. N. (2008). Synthetic mimics of antimicrobial peptides. Biopolymers 90, 83-92. doi: 10.1002/bip.20970

Sorensen, O., Cowland, J. B., Askaa, T., and Borregaard, N. (1997). An ELISA for hCAP-18, the cathelicidin present in human neutrophils and plasma. J. Immunol. Methods 206, 53-59. doi: 10.1016/S0022-1759(97)00084-7

Sullivan, D. J. Jr., Gluzman, I. Y., Russell, D. G., and Goldberg, D. E. (1996). On the molecular mechanism of chloroquine's antimalarial action. Proc. Natl. Acad. Sci. U.S.A. 93, 11865-11870. doi: 10.1073/pnas.93.21.11865

Tanaka, H., Ishibashi, J., Fujita, K., Nakajima, Y., Sagisaka, A., Tomimoto, K., et al. (2008). A genome-wide analysis of genes and gene families involved in innate immunity of Bombyx mori. Insect Biochem. Mol. Biol. 38, 1087-1110. doi: 10.1016/j.ibmb.2008.09.001

Teixeira, C., Vale, N., Pérez, B., Gomes, A., Gomes, J. R. B., and Gomes, P. (2014) "Recycling" classical drugs for malaria. Chem. Rev. 114, 11164-11220. doi: $10.1021 / \mathrm{cr} 500123 \mathrm{~g}$

Tian, C., Gao, B., Rodriguez, M. C., Lanz-Mendoza, H., Ma, B., and Zhu, S. (2008). Gene expression, antiparasitic activity, and functional evolution of the drosomycin family. Mol. Immunol. 45, 3909-3916. doi: 10.1016/j.molimm.2008.06.025

Vale, N., Moreira, R., and Gomes, P. (2009). Primaquine revisited six decades after its discovery. Eur. J. Med. Chem. 44, 937-953. doi: 10.1016/j.ejmech.2008.08.011 van Kan, E. J., Demel, R. A., Breukink, E., van der Bent, A., and de Kruijff, B. (2002). Clananin permeabilizes target membranes via two distinctly different pH-dependent mechanisms. Biochemistry 18, 7529-7539. doi: 10.1021/bi012162t

Vijay, S., Rawat, M., Adak, T., Dixit, R., Nanda, N., Srivastava, H., et al. (2011). Parasite killing in malaria non-vector mosquito Anopheles culicifacies species b: implication of nitric oxide synthase upregulation. PLoS ONE 6:e18400. doi: 10.1371/journal.pone.0018400

Vila-Perelló, M., and Andreu, D. (2005). Characterization and structural role of disulfide bonds in a highly knotted thionin from Pyrularia pubera. Biopolymers 80, 697-707. doi: 10.1002/bip.20270

Visser, B. J., van Vugt, M., and Grobusch, M. P. (2014). Malaria: an update on current chemotherapy. Expert Opin. Pharmacother. 15, 2219-1154. doi: 10.1517/14656566.2014.944499

Vizioli, J., Bulet, P., Charlet, M., Lowenberger, C., Blass, C., Muller, H. M., et al. (2000). Cloning and analysis of a cecropin gene from the malaria vector mosquito, Anopheles gambiae. Insect Mol. Biol. 9, 75-84. doi: 10.1046/j.13652583.2000.00164.x

Vizioli, J., Bulet, P., Hoffmann, J. A., Kafatos, F. C., Muller, H. M., and Dimopoulos, G. (2001). Gambicin: a novel immune responsive antimicrobial peptide from the malaria vector Anopheles gambiae. Proc. Natl. Acad. Sci. U.S.A. 98, 12630-12635. doi: 10.1073/pnas.221466798

Wang, G., Li, X., and Wang, Z. (2009). APD2: the updated antimicrobial peptide database and its application in peptide design. Nucleic Acids Res. 37, D933-D937. doi: 10.1093/nar/gkn823

Wang, S., Ghosh, A. K., Bongio, N., Stebbings, K. A., Lampe, D. J., and Jacobs-Lorena, M. (2012). Fighting malaria with engineered symbiotic bacteria from vector mosquitoes. Proc. Natl. Acad. Sci. U.S.A. 109, 12734-12739. doi: 10.1073/pnas. 1204158109

Wang, Z., and Wang, G. (2004). APD: The antimicrobial peptide database. Nucleic Acids Res. 32, D520-D592. doi: 10.1093/nar/gkh025

Wegscheid-Gerlach, C., Gerber, H. D., and Diederich, W. E. (2010). Proteases of Plasmodium falciparum as potential drug targets and inhibitors thereof. Curr. Top. Med. Chem. 10, 346-367. doi: 10.2174/1568026107907 25461

Wei, S.-Y., Wu, J.-M., Kuo, Y.-Y., Chen, H.-L., Yip, B.-S., Tzeng, S.-R., et al. (2006). Solution structure of a novel tryptophan-rich peptide with bidirectional antimicrobial activity. J. Bacteriol. 188, 328-334. doi: 10.1128/JB.188.1.328-334. 2006

Wells, T. M., and Poll, E. M. (2010). When is enough enough? The need for a robust pipeline of high-quality antimalarials. Discov. Med. 9, 389-398.

White, N. J., Pukrittayakamee, S., Hien, T. T., Faiz, M. A., Mokuolu, O. A., and Dondorp, A. M. (2014). Malaria. Lancet 383, 723-735. doi: 10.1016/S01406736(13)60024-0

WHO. (2012). World Malaria Report. Geneva: World Health Organization.

Wieczorek, M., Jenssen, H., Kindrachuk, J., Scott, W. R. P., Elliott, M., Hilpert, K., et al. (2010). Structural studies of a peptide with immune modulating and direct antimicrobial activity. Chem. Biol. 17, 970-980. doi: 10.1016/j.chembiol.2010.07.007

Wimley, W. C., Selsted, M. E., and White, S. H. (1994). Interactions between human defensins and lipid bilayers: evidence for formation of multimeric pores. Protein Sci. 3, 1362-1373. doi: 10.1002/pro.5560030902

Yang, L., Harroun, T. A., Weiss, T. M., Ding, L., and Huang, H. W. (2001). Barrelstave model or toroidal model? A case study on melittin pores. Biophys. J. 81, 1475-1485. doi: 10.1016/S0006-3495(01)75802-X

Yeaman, M. R., and Yount, N. Y. (2003). Mechanisms of antimicrobial peptide action and resistance. Pharmacol. Rev. 55, 27-55. doi: 10.1124/pr. 55.1 .2

Yi, H. Y., Chowdhury, M., Huang, Y. D., and Yu, X. Q. (2014). Insect antimicrobial peptides and their applications. Appl. Microbiol. Biotechnol. 98, 5807-5822. doi: 10.1007/s00253-014-5792-6

Zasloff, M. (1987). Magainins, a class of antimicrobial peptides from Xenopus skin: isolation, characterization of two active forms, and partial cDNA sequence of a precursor. Proc. Natl. Acad. Sci. U.S.A. 84, 5449-5453. doi: $10.1073 /$ pnas.84.15.5449

Zasloff, M. (2002). Antimicrobial peptides of multicellular organisms. Nature 415, 389-395. doi: 10.1038/415389a

Conflict of Interest Statement: The authors declare that the research was conducted in the absence of any commercial or financial relationships that could be construed as a potential conflict of interest.

Received: 01 November 2014; paper pending published: 11 November 2014; accepted: 26 November 2014; published online: 19 December 2014.

Citation: Vale N, Aguiar L and Gomes P (2014) Antimicrobial peptides: a new class of antimalarial drugs? Front. Pharmacol. 5:275. doi: 10.3389/fphar.2014.00275

This article was submitted to Experimental Pharmacology and Drug Discovery, a section of the journal Frontiers in Pharmacology.

Copyright (c) 2014 Vale, Aguiar and Gomes. This is an open-access article distributed under the terms of the Creative Commons Attribution License (CC BY). The use, distribution or reproduction in other forums is permitted, provided the original author(s) or licensor are credited and that the original publication in this journal is cited, in accordance with accepted academic practice. No use, distribution or reproduction is permitted which does not comply with these terms. 